\title{
Decolorization of Reactive Orange 122 as an Organic Pollutant by the Sonoelectrochemical Process and Toxicity Evaluation
}

\author{
Mohammad Amin Radi',2, Navid Nasirizadeh ${ }^{1,2 *}$, Mohammad Mirjalili', Masoud Rohani Moghadam ${ }^{3}$ \\ ${ }^{1}$ Department of Textile and Polymer Engineering, Yazd Branch, Islamic Azad University, Yazd, Iran \\ ${ }^{2}$ Young Researchers Club, Yazd Branch, Islamic Azad University, Yazd, Iran \\ ${ }^{3}$ Department of Chemistry, Faculty of Sciences, Vali-e-Asr University, Rafsanjan, Iran
}

Corresponding Author: Navid Nasirizadeh, PhD, Associate Professor, Department of Textile and Polymer Engineering, Yazd Branch, Islamic Azad University, Yazd, Iran, Tel: +98-351-8117711, Fax: +98-351-8117550, Email: nasirizadeh@iauyazd.ac.ir

Received August 2, 2018; Accepted September 11, 2018; Online Published September 30, 2018

\begin{abstract}
Introduction: Combined of electrochemistry and ultrasound (sonoelectrochemistry) is one of the advanced oxidation processes (AOPs) for decolorization of color wastewaters. The physicochemical effects of ultrasound improve the electrooxidation of dye solution and decolorization rate.

Materials and Methods: In this study, the decolorization of Reactive Orange 122 (RO122) as an organic pollutant by sonoelectrochemistry has been examined. In this context, the effect of several factors such as hydrogen peroxide concentration, the $\mathrm{pH}$ of solution, colour concentration, and the input voltage on decolorization of colourful solution as a single factor were studied. Based on the results, the optimum hydrogen peroxide concentration for removing the colour with the concentration of $10 \mathrm{mgL}^{-1}$ at 90 minutes was $3.0 \mathrm{mgL}^{-1}$, with pH about 7.0 and the input potential $1.05 \mathrm{~V}$, the process was carried out without the use of hydrogen peroxide as a considered parameter at 90 minutes.

Results: The results revealed that decolourization and removal of chemical oxygen demand (COD) of both methods were $99 \%$ and $70 \%$ in the presence of hydrogen peroxide and $97 \%$ and $95.5 \%$ in the absence of hydrogen peroxide, respectively.

Conclusions: Microbial toxicity test assessed the toxicity of intermediates produced during these two procedures. The results indicated, in the absence of hydrogen peroxide, Pseudomonas aeruginosa bacteria showed better performance on sonoelectrochemical treatment solutions compared to the initial solution, due to absence of colour toxic materials.

Keywords: Textile Wastewater, Azo Dye, Decolorization, Sonoelectrochemistry, Toxicity

Citation: Radi MA, Nasirizadeh N, Mirjalili M, Masoud Moghadam M. Decolorization of Reactive Orange 122 as an organic pollutant by the sonoelectrochemical process and toxicity evaluation. J Appl Biotechnol Rep. 2018;5(3):117-124. doi:10.29252/jabr.05.03.06.
\end{abstract}

\section{Introduction}

Wastewater from fabric and yarn dyeing, textile wastewater discharge to surface water, dyestuff are the main source of emissions to the environment which impose environmental problems. $^{1,2}$ Ten percent to $20 \%$ of reactive dyes are lost in industrial effluents from various manufacturing and processing operations, and nearly $50 \%$ of reactive dyes, due to hydrolysis and react with the $-\mathrm{OH}$ groups of water, could remain in the effluent during dyeing processes. ${ }^{3,4}$ Due to the complex structure of organic pollutants, they can hardly be degraded by single physical, chemical or biological treatment in wastewater, decolorization of wastewater polluted with reactive dyes is closely related to $-\mathrm{C}=\mathrm{C}$ and $-\mathrm{N}=\mathrm{N}$ - bond cleavages or heterocyclic and aromatic rings. ${ }^{3,5}$

At present, 3 types of wastewater treatment are known, namely physical, chemical and biological treatments. Some of these methods are expensive and in some other the intermediate products remain in the solution and they may entail a similar or even higher toxicity than the initial compounds. ${ }^{6}$ Therefore, the use of a mixed method has been examined and suggested by the researchers. The pollutants can be removed using a special class of oxidation technique known as advanced oxidation processes (AOPs) that in recent years by the combination of several oxidation processes has been becoming one of the promising treatment technologies. ${ }^{1,6}$ Sonoelectrochemistry is known as combination of ultrasound irradiation with electrochemistry. Ultrasound enhanced electrochemistry oxidation (US-EO process) is one of the combined technologies..$^{1,7-11}$

Using electrochemical processes as clean methods can result in partial or complete decomposition of the pollutants. Complete mineralization of organic material refers to their oxidation to carbon dioxide. Organic pollutants during electrochemical oxidation treatment are either directly oxidized at the anode or indirect anodic oxidation formed oxidants such as $\mathrm{Cl}_{2}$ or hypochlorite, ozone, hydroxyl radicals

Copyright (C) 2018 The Author(s). This is an open-access article distributed under the terms of the Creative Commons Attribution License (http:// creativecommons.org/licenses/by/4.0), which permits unrestricted use, distribution, and reproduction in any medium, provided the original work is properly cited. 
and $\mathrm{H}_{2} \mathrm{O}_{2} \cdot{ }^{12-15}$ However, direct anodic oxidation (or direct electron transfer to the anode), which yields very poor decontamination, due to the use of low cell voltages and preventing $\mathrm{O}_{2}$ evolution frequently, causes the loss of anode activity. The cause of decrease related to some by-products formed from direct anodic oxidation, which can be adsorbed on its surface. Hence, this procedure is not utilized for wastewater treatment in practice. ${ }^{1}$ Though, using the above mentioned oxidants and their entrance to wastewater, due to environmental issues, is problematic.

An ultrasonic cleaning method is one of the best procedures to improve electrochemical processes. One of the most wellknown effects of ultrasound is the application of acoustic cavitation bubbles in wastewater treatment. ${ }^{16}$ This issue is examined based on electrochemistry and because of high efficiency in decolorization and the destruction of color component has been studied by some researchers. ${ }^{8,17-20}$ It is believed that the reaction in which, the solid is metal and acts as a catalyst, on the solid surface, the liquid center is limited to the solid from one side. Hence, the liquid flow is pushed into the bubble from the other side and explosion is done. Therefore, a liquid jet is formed and targets the solid surface with a speed of $(100 \mathrm{~m} / \mathrm{s}) .^{3}$ Moreover, the ultrasound irradiation (sonochemistry) for the degradation of organic pollutants in water and their undesirable effects in the water environment has been studied.

Irradiation of water using ultrasound causes decomposition of water molecules into extremely reactive radicals, such as $\mathrm{H}^{\cdot}$ and $\mathrm{OH}^{\cdot}{ }^{\cdot 15}$ Therefore, combining these 2 methods in the presence of hydrogen peroxide not only may increase the generation of $\mathrm{OH}$ free radicals but also improve electrooxidation reactions of anode electrode in electrochemical method, so that these factors are efficient in decolorizing from dyestuff solutions. ${ }^{11}$ On the other hand, the combination of the 2 methods in the absence of hydrogen peroxide, by considering the specific effects of ultrasound on the electrode surface, the efficiency of the electrode in dye oxidation would be increased. In addition by removing hydrogen peroxide in the interaction, the decolorization rate, and chemical oxygen demand (COD) removal would also be optimized. In this context, the decolorization ability of sonoelectrochemistry for the removal of a reactive dye (Reactive Orange 122 (RO122) from contaminated solutions and the optimum conditions of this process were studied. Besides, microbial toxicity test assessed the toxicity of intermediates produced by this method: The aim of this study is to achieve, an efficient technology for the treatment of textile effluent.

\section{Materials and Methods}

The C.I. (Color Index) RO122 is shown in (Figure 1) purchased from Korean Rifazol Company and used as received without further purification. All the chemicals used purchased from Merck (Germany). To prepare a stock solution of RO122 with a concentration of $100 \mathrm{ppm}, 10.0 \mathrm{mg}$ of dye was diluted in 100 $\mathrm{mL}$ of distilled water. The buffer solutions made from acetic acid $(\mathrm{pH}=1.0)$ and $\mathrm{H}_{3} \mathrm{PO}_{4}+\mathrm{NaH}_{2} \mathrm{PO}_{4}(\mathrm{pH}=2.0-9.0)$. These $\mathrm{pH}$ values were adjusted to $0.1 \mathrm{molL}^{-1}$ of acetic acid or $\mathrm{H}_{3} \mathrm{PO}_{4}$ with $2.0 \mathrm{molL}^{-1} \mathrm{NaOH}$.

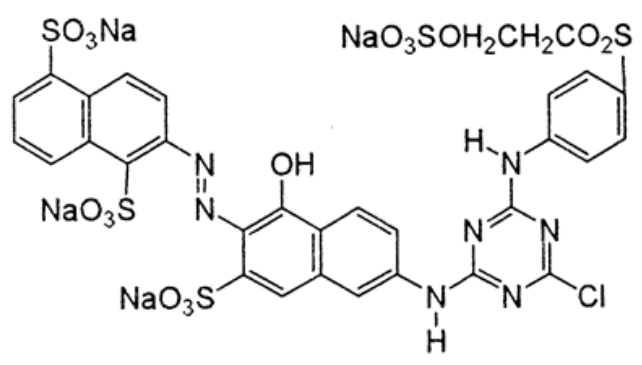

Figure 1. The Chemical Structure of C.I. Reactive Orange 122.

Configuration of 3 electrode electrochemistry and sonoelectrochemistry techniques of a 3-electrode accomplished by Electro Analyzer Apparatus model Sama’e 500 from Research Center of Iran. In the present study, Carbon electrode was used as a working electrode, platinum with a superficial area of approximately $2 \mathrm{~cm}^{2}$ was applied as an auxiliary electrode and saturated calomel electrode (Azar Electrode Co, Iran) was the reference electrode.

The ultrasound bath has 2 transducers located at on the bottom of the bath case, at the frequency of $35 \mathrm{kHz}$ with the maximum power of $150 \mathrm{~W}$. For sonoelectrochemical procedure, the electrochemical cell was placed in an ultrasonic bath. Sonication was achieved at low frequencies $(35 \mathrm{kHz})$ using Vicenza ultrasound E Euronda S.P.A model, 4D (Italy) with 2 ultrasound transducers under the steel container of the bath case. The average power output of the generator was 150 $\mathrm{W} / \mathrm{cm}^{2}$. Moreover, glass vessel reactor was applied and the electrochemical cell was placed into the ultrasonic bath for sonoelectrochemical procedure (Figure 2).

A UV-Vis spectrophotometer "Varian Cary 100 model (Australian)" was used for the determination of dye concentrations at the maximum of absorbance, and the amount of residual C.I RO122. The $\mathrm{pH}$ measured with a Metrohm model $691 \mathrm{pH} / \mathrm{mV}$ meter.

In the following steps, $0.5 \mathrm{~mL}$ of RO122 $\left(100 \mathrm{mgL}^{-1}\right), 5.0 \mathrm{~mL}$ buffer solution $(\mathrm{pH}=7.0)$ and $15 \mathrm{ml} \mathrm{H}_{2} \mathrm{O}_{2}\left(10 \mathrm{molL}^{-1}\right)$ were added to $50 \mathrm{~mL}$ volumetric flask and diluted to the volume with double-distilled water. Solutions were treated using the 3 -electrode electro analyzer for 90 minutes at $1.05 \mathrm{~V}$ potential to the working electrode. Likewise, decolorization of the dye was done in the ultrasonic bath with $35 \mathrm{kHz}$ frequency by the 3 -electrode electro analyzer for 90 minutes at $1.05 \mathrm{~V}$ potential to the working electrode.

The following equation was used to determine the percentage of decolorization:

Percent of decolorization $=\left(1-\mathrm{C}_{\mathrm{t}} / \mathrm{C}_{0}\right) \times 100$

In this equation, $C_{t}$ is the dye concentration after degradation process and $C_{0}$ is the primary concentration of the dye.

The process of removing organic pollutants by microorganisms called bioabsorbtion, or biodegradation. In the present study, we have examined, the biodegradability of intermediates derived from the destruction of RO122 color by the sonoelectrochemistry in the presence of nano $\mathrm{TiO}_{2}$. For this purpose, the toxicity dye solution using Pseudomonas aeruginosa (PTCC 1707) preparation of Iranian Biological Recourse Center (IBRC) were studied. 


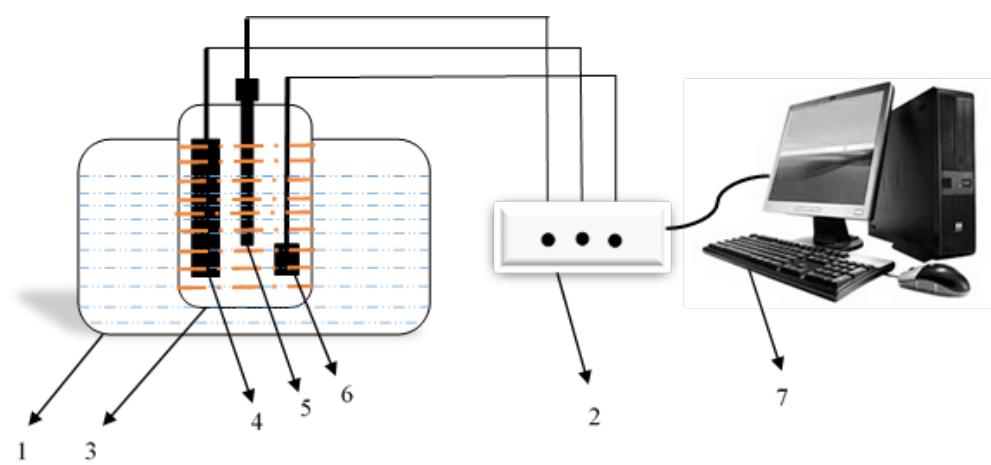

Figure 2. Experimental Setup of Sonoelectrochemical System. 1. Ultrasonic bath; 2. Three electrode Electro Analyzer Apparatus; 3. Glass vessel as the electrochemical cell; 4. Carbon electrode (working electrode); 5. Platinum plate electrode (auxiliary electrode); 6 . Saturated calomel electrode (reference electrode); 7 . Computer control.

Considering, the selected bacterium was not exposed to RO122 previously and is normally/mainly destroyed when exposed to a colored solution, the bacterial rejuvenation process to the color and the determination of the optimum conditions for the growth of the bacteria carried out by the use of a single-agent method. For this aim, some agar nutrient culture was made and, before pouring into the culture, $100 \mathrm{mgL}^{-1}$ of dye was measured and added to the culture. Subsequently, medium shrinkage was done in a completely sterile condition; and the bacterium was fed linearly on the medium. Then, plates were incubated at $37^{\circ} \mathrm{C}$ for 24 hours. After 24 hours, resistant colonies grew on a dye-containing media.

In order to prepare $\mathrm{pH} 5$ to 9 , the $\mathrm{pH}$ meter was used and chloride acid and sodium hydroxide were added to culture medium. Thereafter, the bacterium was cultured in the media. After 24 hours, $50 \mathrm{mg}$ of RO122 was added to culture medium, and the optimal condition of biodegradation by bacteria was investigated. Therefore, the optimum $\mathrm{pH}$ of culture was considered $(\mathrm{pH}=8)$ and remained fix during the experiment.

At the next step, $4 \mathrm{~mL}$ of samples were taken within 72 (3 days) interval at 32, 34, 36, 38 and 40 hours and centrifuged at $4000 \mathrm{rpm}$ for 10 minutes. The solid-liquid phase separation was done and the absorbance of the supernatant and the dye decolorization percentage was determined. To evaluate the effect of color concentration on the rate of decomposition by the bacteria, dye concentrations of $25-125 \mathrm{mgL}^{-1}$ were prepared. The amount of dye presented in the medium after optimal time in the optimum $\mathrm{pH}$ was analyzed using spectrophotometric apparatus. To evaluate the effect of temperature on decolorization of orange dye by bacteria, the remained dye after 54 hours in temperatures of 32, 34, 36,38 , and $40^{\circ} \mathrm{C}$ was analyzed. In the final stage, the rate of decolorization by the bacterium in optimum conditions was calculated.

To perform toxicity testing, the test solutions were prepared beforeand after the decolorization process. Then, thereinforced bacteria were agglomerated under optimal conditions of $\mathrm{pH}=$ 8 , temperature $38^{\circ} \mathrm{C}$ and 48 hours on the initial color solution and solutions after the decolorization process.

\section{Results}

Figure 3 indicates the effect of adding different concentrations of $\mathrm{H}_{2} \mathrm{O}_{2}$. As illustrated in Figure 3, major improvements have been made in response to increasing oxidizing agent concentration up to certain value. However, the maximum dye decolorization occurred with the addition of $3 \mathrm{molL}^{-1}$ of hydrogen peroxide. The results showed that after 60 minutes the decolorization rate in the presence of hydrogen peroxide is higher than its rate in the absence of such substance. Though, the decolorization rate for both methods remains approximately the same over time.

The effect of $\mathrm{pH}$ on the decolorization reaction was investigated in different $\mathrm{pH}$ values. We prepared solutions with a concentration of $10 \mathrm{mgL}^{-1}$ at different $\mathrm{pH}$ values with the input potential of $1.05 \mathrm{~V}$ after 90 minutes. Figure 4 indicated the behavior of solution in the presence of $\mathrm{H}_{2} \mathrm{O}_{2}$ with concentration of $3 \mathrm{molL}^{-1}$ and the absence of $\mathrm{H}_{2} \mathrm{O}_{2}$ The $\mathrm{pH} 7.0$ was considered as optimized $\mathrm{pH}$ value, since, decolorization $\mathrm{pH}$ rate was increased in both cases up to 7.0 and subsequently it was decreased. However, by comparing Figure $4 \mathrm{~A}$ and $4 \mathrm{~B}$ at 90 minutes, it can be concluded that the

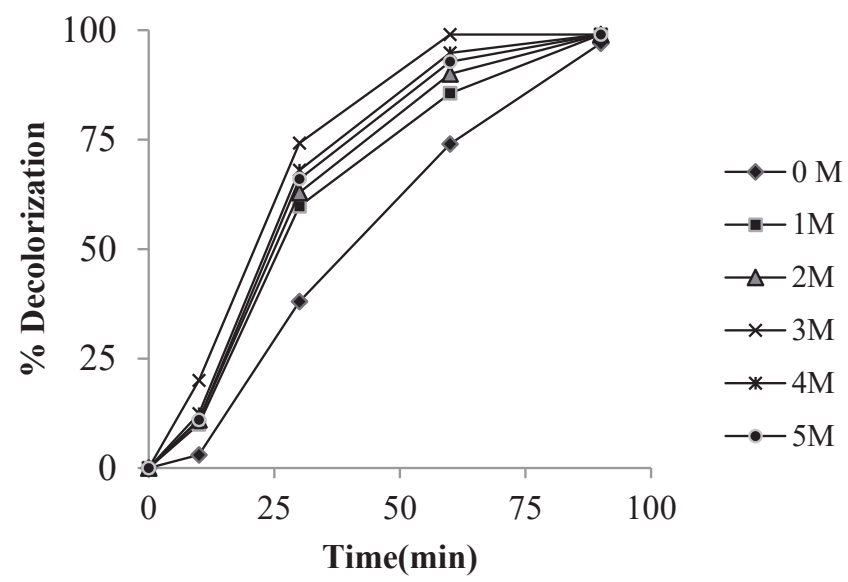

Figure 3. The Effect of $\mathrm{H} 2 \mathrm{O} 2$ Concentration on Decolorization Efficiency, Dye Concentration $10 \mathrm{mgL}^{-1}$, Sonication Time 90 minutes, and Sonoelectrochemistry Method Input Potential of $1.05 \mathrm{~V}$ and $\mathrm{pH}$ 7.0 . 
decolorization rate in the presence of hydrogen peroxide is higher than in the absence of it.

The effect of initial RO122 concentration was investigated at different levels, including 10, 50, 100 and $150 \mathrm{mgL}^{-1}$ and the obtained results are indicated in Figure 5. As shown in Figure 5 , with increase in the dye concentration, the decolorization percent is reduced.

Different potentials $(0.25,0.5$ and $1.05 \mathrm{~V})$ were applied to carbon active electrode. From Figure $6 \mathrm{~A}$ and $6 \mathrm{~B}$ it can be seen that the increasing electric voltage, lead to increasing of dye degradation in the reaction systems. Higher applied potential causes destruction of the working electrode. So, $1.05 \mathrm{~V}$ was selected for further investigations. Figure $6 \mathrm{~A}$ and $6 \mathrm{~B}$ indicate an increase in voltage, lead to increase of dye degradation, and thus, the highest possible voltage was picked out.

In addition, the cyclic voltammogram of RO122 solution $\left(10 \mathrm{mgL}^{-1}\right)$ at $\mathrm{pH}=7.0$ in surface of glassy carbon electrode (Figure 7) indicated that the oxidation of RO122 is an irreversible process. Indeed, when colored solution is exposed to an electric current, the oxidation took place at the anode oxidation procedure of the RO122 dye does not have any return in cathode electrode at all. Therefore, the decolorization of such dye can be done properly in a cell with working, auxiliary and reference electrodes, and does not need anode and cathode cell separation. Considering this matter, even by eliminating hydrogen peroxide of the reaction, the decolorization rate was acceptable. In addition, this graph shows that, oxidation potential of the dye is about $1.05 \mathrm{~V}$ that confirms results obtained.

The degradation products derived from sonoelectrochemical
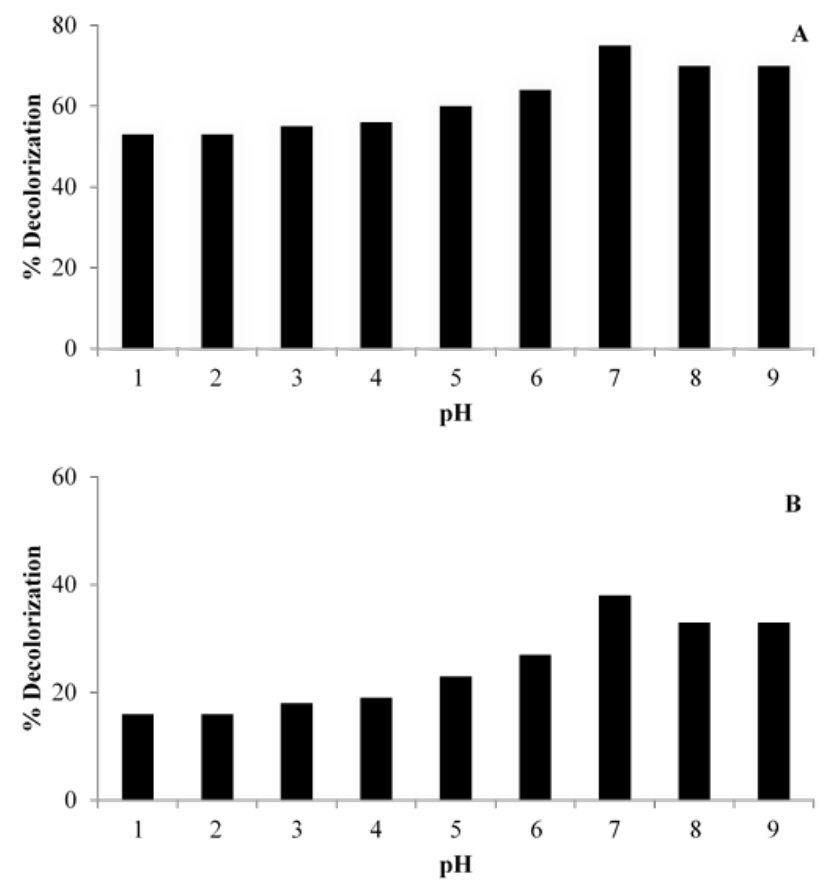

Figure 4. The Effect of $\mathrm{pH}$ on Decolorization Rate Dye Concentration $10 \mathrm{mgL}^{-1}$, Sonication Time 30 Minutes, Sonoelectrochemistry Method Input Potential of $1.05 \mathrm{~V}$, (A) in the Presence of $3 \mathrm{molL}^{-1} \mathrm{H}_{2} \mathrm{O}_{2^{\prime}}$ (B) in the absence of $\mathrm{H}_{2} \mathrm{O}_{2}$.
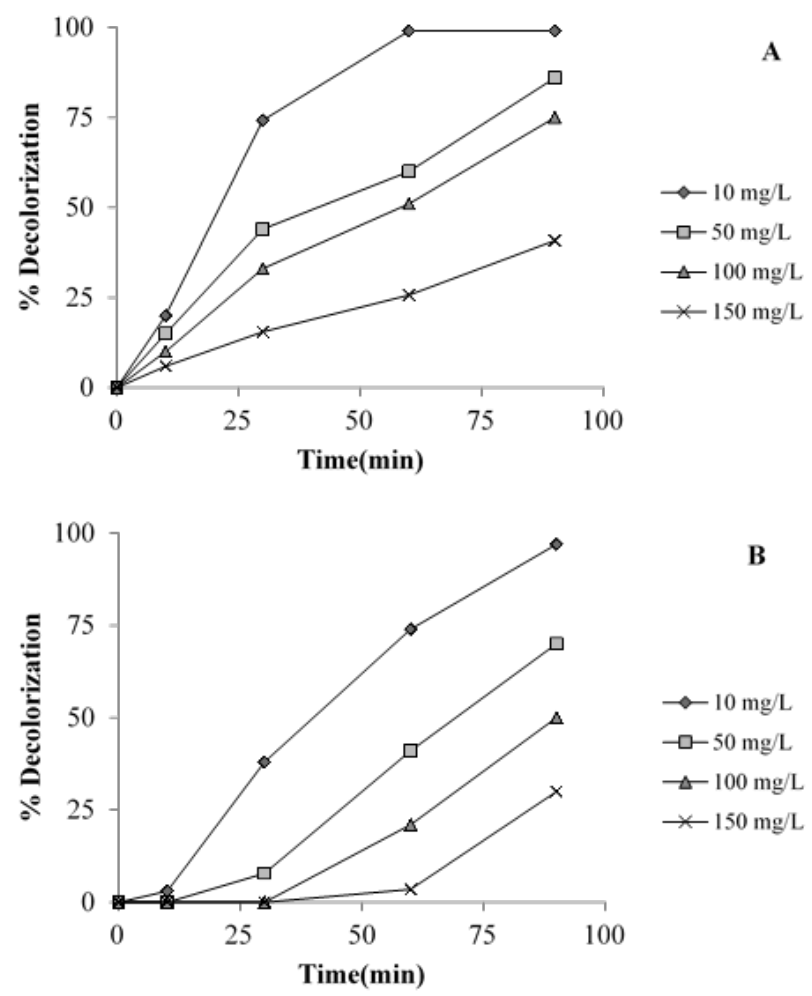

Figure 5. The Effect of Initial Dye Concentration on Decolorization Rate Sonication Time 90 Minutes, Sonoelectrochemistry Method Input Potential of $1.0 \mathrm{~V}$ and pH 7.0, (A) in the Presence of $3 \mathrm{molL}^{-1} \mathrm{H}_{2} \mathrm{O}_{2}$, (B) in the Absence of $\mathrm{H}_{2} \mathrm{O}_{2}$.
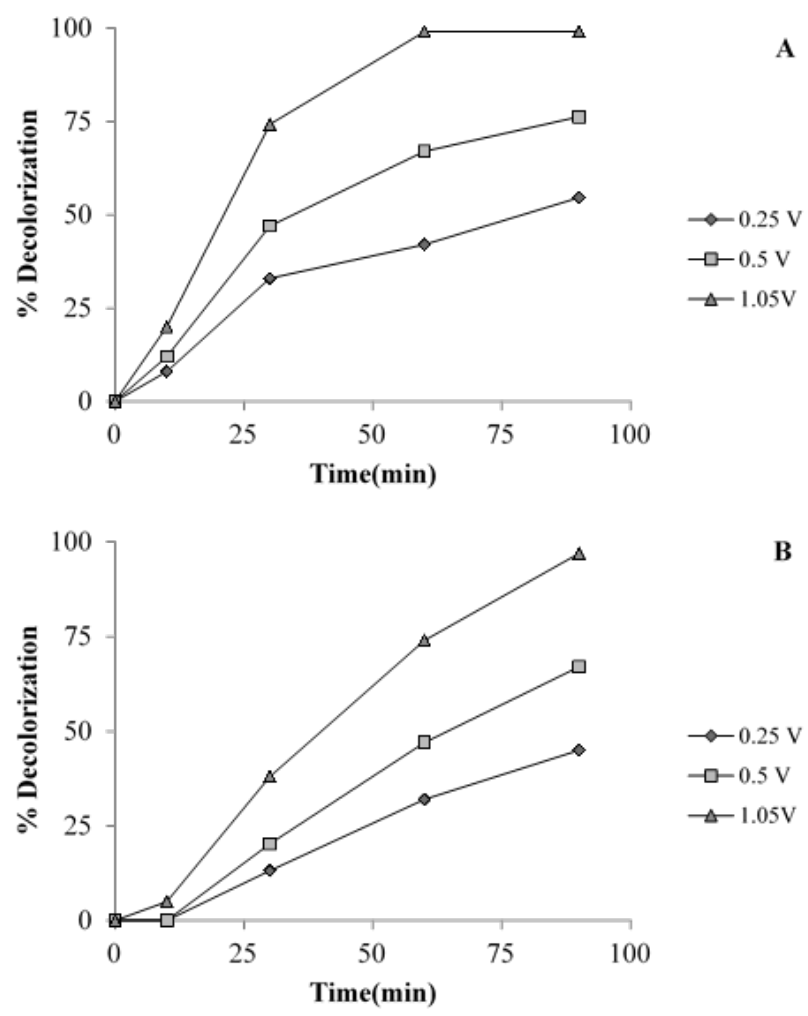

Figure 6. Voltage Effect on Decolorization Rate Dye Concentration 10 $\mathrm{mgL}^{-1}$, Sonication Time 90 Minutes and $\mathrm{pH}$ 7.0, $(\mathrm{A})$ in the Presence of 3 molL $^{-1} \mathrm{H}_{2} \mathrm{O}_{2^{\prime}}$ (B) in the Absence of $\mathrm{H}_{2} \mathrm{O}_{2}$. 


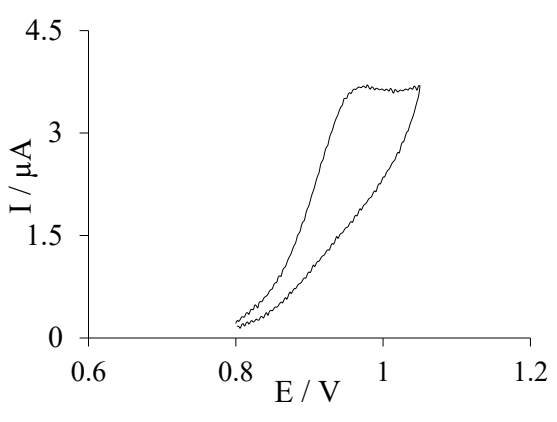

Figure 7. Cyclic Voltammogram pH 7.0 and Dye Concentration 10 $\mathrm{mgL}^{-1}$ of C.I Reactive Yellow.

process in absence of hydrogen peroxide can be detected by gas chromatograph-mass spectrometer (GC/MS). Therefore, the degradation products were identified using GC-MS an Agilent 7890A gas chromatography coupled with an Agilent 5975C inert MSD with Triple-Axis Detector (Agilent Technologies, Palo Alto, CA). The Sample was collected from end stage and was conducted according to the procedure reported in the literature. ${ }^{21}$

The COD removal percentage for both methods with and without the use of hydrogen peroxide was studied. As it is shown in Table 1, in the method in which decolorization was done in the presence of hydrogen peroxide, the amount of COD recovery at 90 minutes was about $70 \%$ and in the absence of hydrogen peroxide, the amount of COD removing improved to $95.5 \%$ at 90 minutes.

By examining the biodegradability of intermediate materials derived from color degradation in sonoelectrochemical methods, both in absence and presence of hydrogen peroxide indicated that bacterial growth was appropriate in the absence of hydrogen peroxide, while Pseudomonas bacteria had no growth in the initial color solution. The results of this test are displayed in Figure 8.

\section{Discussion}

Many studies have been conducted to find suitable bacteria for the removal of reactive colors, particularly those with astringent structure, from textile wastewaters. ${ }^{22-28}$ The toxicity of wastewater due to high variety of colors and low capacity of removing color microorganism is a crucial problem which affected many living microorganisms.

Thus, by using the sonoelectrochemistry method, which is a subset of advanced oxidation methods, it is possible to facilitate the destruction of the astringent structure RO122 color with a convenient time, low cost, and improve the activity of a wide range of living microorganisms.

The conducted microbial test indicated that, in the sonoelectrochemistry method, the dye molecules have been degraded and produced intermediates which can be dissipated and consumed by microorganisms in the environment. Though, in the presence of hydrogen peroxide in sonoelectrochemistry method, the process of color degradation of color molecules has been done properly. It seems that the presence of hydrogen peroxide in the environment, damage to bacterial growth. Therefore, the sonoelectrochemistry method can easily improve the desired textile wastewater purification by combination with biological methods.

Oxidation hydrogen peroxide is one of the well-known AOP methods for wastewater decolorizatio. ${ }^{4}$ Ultrasonic irradiation in aqueous solution, includes the formation of free radicals as a consequence of cavitation. The thermal decomposition of the water vapour and $\mathrm{H}_{2} \mathrm{O}_{2}$ in a cavitation bubble leads to the formation of $\mathrm{HO}, \mathrm{H}$ and $\mathrm{HOO}$ radicals. ${ }^{29}$

According to Figure 9 we can predict the mechanism of the reaction of the hydrogen peroxide in colored solution based on the results of GC/MS.

The physical effects of ultrasound improve the decolorization rate by enhancing the electrocatalytic oxidation and the production of free radicals, derived from additional hydroxyl radical to react with the substrate. ${ }^{4,8,18-20,29,30}$ Hydrogen

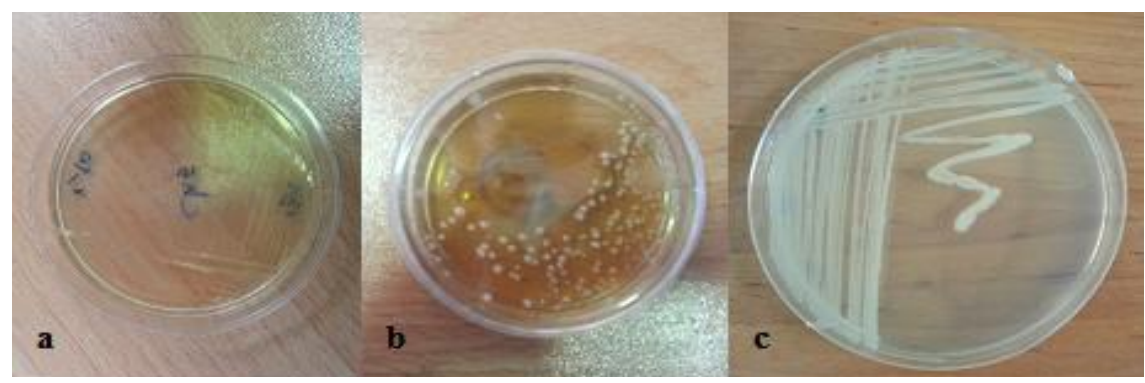

Figure 8. (a) Results of microbial test of initial color solution in optimal conditions and time of 48 hours; (b) Results of microbial test of the color solution treated with sonoelectrochemistry in optimal conditions and 48 hours; (c) Results of microbial test performed with Sonoelectrochemistry/hydrogen peroxide method under optimal conditions and 48 hours

Table 1. The Comparison of COD and Decolorization With and Without Use of $\mathrm{H} 2 \mathrm{O} 2$

\begin{tabular}{|c|c|c|c|c|c|c|c|}
\hline \multirow{2}{*}{ Method } & \multicolumn{5}{|c|}{ Optimum Conditions } & \multirow{2}{*}{ COD Removal \% } & \multirow{2}{*}{ Decolorizaton \% } \\
\hline & Time (min) & $\mathrm{H}_{2} \mathrm{O}_{2}\left(\mathrm{mgL}^{-1}\right)$ & Potential (V) & $\mathrm{pH}$ & Dye $\left(\mathrm{mgL}^{-1}\right)$ & & \\
\hline Sonoelectrochemistry with $\mathrm{H}_{2} \mathrm{O}_{2}$ & 90 & 3 & 1.05 & 7 & 10 & 70 & 99 \\
\hline
\end{tabular}


peroxide increases the formation rate of hydroxyl radicals in 2 ways. The reduction of $\mathrm{H}_{2} \mathrm{O}_{2}$ at the conduction band and/ or the self-decomposition as a result of ultrasound irritation would produce hydroxyl radicals., ${ }^{429-31}$

Sonoelectrochemical degradation in absence of $\mathrm{H}_{2} \mathrm{O}_{2}$, lead to acceptable better results compare in the presence of oxidizing agent after 90 minutes of the decolorization time. Degassing of the electrode surface by ultrasound prevents gas bubble accumulation interfering with the passage of current and agitation (via cavitation) at the electrode surface, assists/ boosts ion transport across the electrode double layer during the electrochemical process and also reduces ion depletion in the diffusion layer. ${ }^{32}$

The mechanism of ultrasound action in the solution is directly related to cavitation, the microbubbles formed by ultrasound affect soluble materials. The breakdown of microbubbles cause formation large shear forces in the fluid surrounding the bubble, which lead to breaking the chemical bond in the dissolved polymer materials in the liquid, on the other hand, by producing a microbubble, 3 regions including the inside of the bubble, the interface between the liquid-gas and the perimeter of the bubble, were formed, each of them had effect on solution. Therefore, the inside of the bubble can be considered as a high energy microreactor.

Due to the chemical change of internal molecules of the cavity bubble lead to the formation of $\mathrm{OH}$ and $\mathrm{H}$ radicals in the gas phase. Heat affected all of the components which used in the reaction with a radical hydroxyl liquid and caused a chemical change. ${ }^{33}$ During ultrasound radiation, the small amounts of $\mathrm{OH}$ radicals are produced in the bubble, which conducted an additional reaction and produced $\mathrm{H}_{2} \mathrm{O}_{2}$. At the interface between the liquid-gas, a similar reaction occurs within the bubble, but the reaction occurs in the aqueous phase. ${ }^{34}$ The highly oxidizing species $\mathrm{OH}$ or with other mild species in the bubble is reacted or is gone into solution. ${ }^{35}$

Radicals introduced into the solution are reacted with other molecules and new radicals or oxidants dispersed in the liquid. Subsequently, free radical release and burning in liquid occur on a hot bubble shell. The reaction region has a little polarization, so it allows the hydrophobic solutions to be easily accumulated. ${ }^{36}$ Here are some subjects to be considered. ${ }^{37}$

The $\mathrm{OH}$ radicals introduced into the liquid produced in the bubble which is found transiently in the liquid, and the $\mathrm{H}_{2} \mathrm{O}_{2}$ are also generated by reacting $\mathrm{OHs}$ at the interface between the liquid-gas surfaces. However, in the sonoelectrochemistry reaction, auxiliary oxidation solution such as hydrogen peroxide is reacted with the radicals and high-level material in solution. Though, the conditions in which hydrogen peroxide oxidizing agent was not used, hydroxyl radicals and hydrogen peroxide produced by ultrasound involved to a reaction with the materials inside the solution.

The $\mathrm{pH}$ value is a critical parameter in determining the performance of sonoelectrochemical processes. At normal conditions, the main anion is $\mathrm{OH}^{-}$, which changes into $\mathrm{OH} \cdot$ radical by losing electron on the anode surface. The ultrasonic waves increase transfer of $\mathrm{OH}^{-}$ions towards anode, and the increased production of these $\mathrm{OH}^{\circ}$, eventually, enhance the oxidation process of RO122. ${ }^{38-40}$

Higher hydrophobic compounds are more easily decomposed by the hot cavitation's bubbles and/or $\mathrm{OH}^{*}$ radicals, formation from the water and $\mathrm{H}_{2} \mathrm{O}_{2}$ sonolysis. ${ }^{41}$

Moreover, by increasing the dye concentration, Decolorization percent is decreased. This behavior is one of the characteristics of AOP. ${ }^{42}$ The decrease in the decolorization efficiency in sonoelectrochemical method might be because of: (I) high concentration of dye, lead to enhances the number of dye molecules, but didn't has effect on the $\mathrm{OH}$ radical concentration; therefore, the removal rate becomes low; (II) with the increase in initial dye concentration, the cavities and $\mathrm{OH}$ approached saturation; (III) increase in concentration, increase the possibility of the generation of more inorganic anions which may challenge the organic species for the reaction with $\mathrm{OH}$ radicals. ${ }^{41}$

One of the features of advanced oxidation systems is the

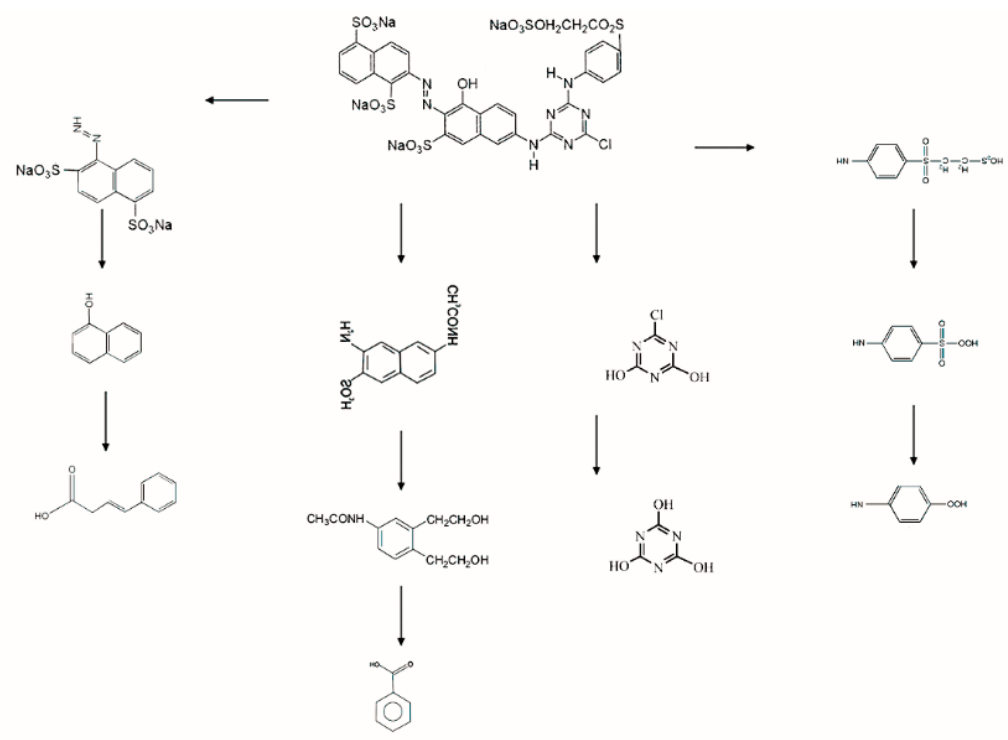

Figure 9. The Mechanism of the Reaction of Degradation of RO122. 
reduction of the decolorization percentage in while the initial dye concentration is high. Therefore, the increase of in the number of dye molecules to the presence of $\mathrm{OH}$ radical in the solution. Another important point is, the possibility of production of mineral anions and their competition with organic species in the reaction with high $\mathrm{OH}$ radicals.

\section{Conclusions}

In this study, the use of sonoelectrochemistry in presence and absence of $\mathrm{H}_{2} \mathrm{O}_{2}$ in decolorization of the C.I RO122 with azoic base was examined. The sonoelectrochemistry method is able to completely decolorize this colored solution using $\mathrm{H}_{2} \mathrm{O}_{2}$ at 90 minutes, and COD removal is about $70 \%$. The obtained results indicate that, factors such as hydrogen peroxide concentration, colored solution concentration, and $\mathrm{pH}$ and the input voltage has an effect on this method. With optimizing the mentioned parameters, sonoelectrochemical in the absence of $\mathrm{H}_{2} \mathrm{O}_{2}$ is capable of decolorizing $97 \%$ at 90 minutes and have the COD of $95.5 \%$. Based on the results of this experiment, hydrogen peroxide and the radicals derived from it remain stable to the end of the reaction, which cause a reduction in COD removal, On the other hand, the analysis of bacterial growth treated with sonoelectrochemistry showed that, in the presence of hydrogen peroxide, the number of bacteria decreased which is not acceptable for the environment. As the desired dye only participates in anode oxidation reaction, its decolorization by the use of sonoelectrochemistry method in the absence of $\mathrm{H}_{2} \mathrm{O}_{2}$, considered as an applicable method.

\section{Authors' Contributions}

All authors equally contributed to the present study.

\section{Conflict of Interest Disclosures}

The authors declare they have no conflicts of interest.

\section{References}

1. Wang X, Yao Z, Wang J, Guo W, Li G. Degradation of reactive brilliant red in aqueous solution by ultrasonic cavitation. Ultrason Sonochem. 2008;15(1):43-48. doi:10.1016/j. ultsonch.2007.01.008.

2. Yavuz Y, Shahbazi R, Koparal AS, Ogutveren UB. Treatment of Basic Red 29 dye solution using iron-aluminum electrode pairs by electrocoagulation and electro-Fenton methods. Environ Sci Pollut Res Int. 2014;21(14):8603-8609. doi:10.1007/s11356-014-27898.

3. He Z, Song S, Zhou H, Ying $H$, Chen J. C.I. Reactive Black 5 decolorization by combined sonolysis and ozonation. Ultrason Sonochem. 2007;14(3):298-304. doi:10.1016/j. ultsonch.2006.09.002.

4. Voncina DB, Le Marechal AM. Reactive dye decolorization using combined ultrasound/H2O2. Dyes Pigm. 2003;59(2):173-179. doi:10.1016/S0143-7208(03)00101-3.

5. Zhao G, Shen S, Li M, Wu M, Cao T, Li D. The mechanism and kinetics of ultrasound-enhanced electrochemical oxidation of phenol on boron-doped diamond and Pt electrodes. Chemosphere. 2008;73(9):1407-1413. doi:10.1016/j.chemosphere.2008.08.008.

6. Sires I, Brillas E, Oturan MA, Rodrigo MA, Panizza M. Electrochemical advanced oxidation processes: today and tomorrow. A review. Environ Sci Pollut Res Int. 2014;21(14):83368367. doi:10.1007/s11356-014-2783-1.

7. Yang B, Zuo J, Tang X, et al. Effective ultrasound electrochemical degradation of methylene blue wastewater using a nanocoated electrode. Ultrason Sonochem. 2014;21(4):1310-1317. doi:10.1016/j.ultsonch.2014.01.008.

8. Somayajula A, Asaithambi $\mathrm{P}$, Susree $M$, Matheswaran $M$. Sonoelectrochemical oxidation for decolorization of Reactive Red 195. Ultrason Sonochem. 2012;19(4):803-811. doi:10.1016/j. ultsonch.2011.12.019.

9. Sharma SK, Sanghi R. Advances in Water Treatment and Pollution Prevention. Netherlands: Springer; 2012:460.

10. Esclapez MD, Tudela I, Diez-Garcia MI, Saez V, Bonete P. Towards the complete dechlorination of chloroacetic acids in water by sonoelectrochemical methods: Effect of the cathode material on the degradation of trichloroacetic acid and its degradation by-products. Appl Catal B Environ. 2015;166-167:66-74. doi:10.1016/j.apcatb.2014.10.061.

11. Radi MA, Nasirizadeh N, Rohani-Moghadam M, Dehghani M. The comparison of sonochemistry, electrochemistry and sonoelectrochemistry techniques on decolorization of C.I Reactive Blue 49. Ultrason Sonochem. 2015;27:609-615. doi:10.1016/j. ultsonch.2015.04.021.

12. Brillas E. Martinez-Huitle CA. Decontamination of wastewaters containing synthetic organic dyes by electrochemical methods. An updated review. Appl Catal B Environ. 2015;166-167:603-643. doi:10.1016/j.apcatb.2014.11.016.

13. Comninellis C. Electrocatalysis in the electrochemical conversion/ combustion of organic pollutants for waste water treatment. Electrochim Acta. 1994;39(11-12):1857-1862. doi:10.1016/00134686(94)85175-1.

14. Sanroman MA, Pazos M, Cameselle C. Optimisation of electrochemical decolourisation process of an azo dye, Methyl Orange. J Chem Technol Biotechnol. 2004;79(12):1349-1353. doi:10.1002/jctb.1098.

15. Xu LJ, Chu W, Graham N. Sonophotolytic degradation of dimethyl phthalate without catalyst: analysis of the synergistic effect and modeling. Water Res. 2013;47(6):1996-2004. doi:10.1016/j. watres.2013.01.015.

16. Li M, Li JT, Sun HW. Decolorizing of azo dye Reactive red 24 aqueous solution using exfoliated graphite and $\mathrm{H} 2 \mathrm{O} 2$ under ultrasound irradiation. Ultrason Sonochem. 2008;15(5):717-723. doi:10.1016/j.ultsonch.2007.10.001.

17. Lorimer JP, Mason TJ, Plattes M, Phull SS. Dye effluent decolourisation using ultrasonically assisted electro-oxidation. Ultrason Sonochem. 2000;7(4):237-242. doi:10.1016/S13504177(99)00045-0.

18. Yasman Y, Bulatov V, Gridin VV, et al. A new sono-electrochemical method for enhanced detoxification of hydrophilic chloroorganic pollutants in water. Ultrason Sonochem. 2004;11(6):365-372. doi:10.1016/j.ultsonch.2003.10.004.

19. Rivera $M$, Pazos $M$, Sanroman MA. Improvement of dye electrochemical treatment by combination with ultrasound technique. J Chem Technol Biotechnol. 2009;84(8):1118-1124. doi:10.1002/jctb.2141.

20. Mason TJ, Lorimer JP. General Principles, in Applied Sonochemistry. Applied sonochemistry: uses of power ultrasound in chemistry and processing. Wiley-VCH Verlag GmbH \& Co. KGaA; 2003:25-74. doi:10.1002/352760054X.

21. Zhang $X B$, Dong WY, Yang W. Decolorization efficiency and kinetics of typical reactive azo dye RR2 in the homogeneous Fe(II) catalyzed ozonation process. Chem Eng J. 2013;233:14-23. doi:10.1016/j.cej.2013.07.098.

22. Jadhav JP, Kalyani DC, Telke AA, Phugare SS, Govindwar SP. Evaluation of the efficacy of a bacterial consortium for the removal of color, reduction of heavy metals, and toxicity from textile dye effluent. Bioresour Technol. 2010;101(1):165-173. doi:10.1016/j. biortech.2009.08.027.

23. Saratale RG, Saratale GD, Kalyani DC, Chang JS, Govindwar SP. Enhanced decolorization and biodegradation of textile azo dye Scarlet $\mathrm{R}$ by using developed microbial consortium-GR. Bioresour Technol. 2009;100(9):2493-2500. doi:10.1016/j. biortech.2008.12.013. 
24. Song L, Shao Y, Ning S, Tan L. Performance of a newly isolated salt-tolerant yeast strain Pichia occidentalis G1 for degrading and detoxifying azo dyes. Bioresour Technol. 2017;233:21-29. doi:10.1016/j.biortech.2017.02.065.

25. Sen SK, Raut S, Bandyopadhyay P, Raut S. Fungal decolouration and degradation of azo dyes: a review. Fungal Biol Rev. 2016;30(3):112-133. doi:10.1016/j.fbr.2016.06.003.

26. Tan L, He M, Song L, Fu X, Shi S. Aerobic decolorization, degradation and detoxification of azo dyes by a newly isolated salt-tolerant yeast Scheffersomyces spartinae TLHS-SF1. Bioresour Technol. 2016;203:287-294. doi:10.1016/j.biortech.2015.12.058.

27. Solis M, Solis A, Perez HI, Manjarrez N, Flores M. Microbial decolouration of azo dyes: a review. Process Biochem. 2012;47(12):1723-1748. doi:10.1016/j.procbio.2012.08.014.

28. Saratale RG, Saratale GD, Chang JS, Govindwar SP. Bacterial decolorization and degradation of azo dyes: a review. J Taiwan Inst Chem Eng. 2011;42(1):138-157. doi:10.1016/j.jtice.2010.06.006.

29. Song YL, Li JT. Degradation of C.I. Direct Black 168 from aqueous solution by fly ash/H2O2 combining ultrasound. Ultrason Sonochem. 2009;16(4):440-444. doi:10.1016/j. ultsonch.2008.12.011.

30. Ai Z, Li J, Zhang L, Lee S. Rapid decolorization of azo dyes in aqueous solution by an ultrasound-assisted electrocatalytic oxidation process. Ultrason Sonochem. 2010;17(2):370-375. doi:10.1016/j.ultsonch.2009.10.002.

31. Abbasi M, Razzaghi-Asl N. Sonochemical degradation of Basic Blue 41 dye assisted by nanoTiO2 and H2O2. J Hazard Mater. 2008;153(3):942-947. doi:10.1016/j.jhazmat.2007.09.045.

32. Lorimer JP, Mason TJ, Plattes M, Phull SS, Walton DJ. Degradation of dye effluent. Pure Appl Chem. 2001;73(12):1957-1968. doi:10.1351/pac200173121957.

33. Adewuyi YG. Sonochemistry: environmental science and engineering applications. Ind Eng Chem Res. 2001;40(22):46814715. doi:10.1021/ie010096l.

34. Feldman D. Sonochemistry, theory, applications and uses of ultrasound in chemistry, by Timothy J. Mason and J. Phillip Lorimer,
Wiley-Interscience, New York, 1989, 252 pp. Price: \$87.95. J Polym Sci C Polym Lett. 1989;27(13):537-537. doi:10.1002/ pol.1989.140271309.

35. Mason TJ, Lorimer JP. Sonoelectrochemistry. In: Applied Sonochemistry. Wiley-VCH Verlag GmbH \& Co. KGaA; 2003:225266. doi:10.1002/352760054X.ch6.

36. Vajnhandl S, Le Marechal AM. Ultrasound in textile dyeing and the decolouration/mineralization of textile dyes. Dyes Pigm. 2005;65(2):89-101. doi:10.1016/j.dyepig.2004.06.012.

37. Chowdhury $\mathrm{P}$, Viraraghavan T. Sonochemical degradation of chlorinated organic compounds, phenolic compounds and organic dyes - a review. Sci Total Environ. 2009;407(8):24742492. doi:10.1016/j.scitotenv.2008.12.031.

38. Siddique M, Farooq R, Khan ZM, Khan Z, Shaukat SF. Enhanced decomposition of reactive blue 19 dye in ultrasound assisted electrochemical reactor. Ultrason Sonochem. 2011;18(1):190196. doi:10.1016/j.ultsonch.2010.05.004.

39. Bonete Ferrandez PL, Esclapez MD, Bernal VS, Gonzalez-Garcia J. Sonoelectrochemistry in Environmental Applications. In: Pollet BG, ed. Power Ultrasound in Electrochemistry. John Wiley \& Sons, Ltd; 2012:101-139. doi:10.1002/9781119967392.ch4.

40. BasiriParsa J, Rezaei M, Soleymani AR. Electrochemical oxidation of an azo dye in aqueous media investigation of operational parameters and kinetics. J Hazard Mater. 2009;168(2-3):9971003. doi:10.1016/j.jhazmat.2009.02.134.

41. Okitsu K, Iwasaki K, Yobiko Y, Bandow H, Nishimura R, Maeda Y. Sonochemical degradation of azo dyes in aqueous solution: a new heterogeneous kinetics model taking into account the local concentration of $\mathrm{OH}$ radicals and azo dyes. Ultrason Sonochem. 2005;12(4):255-262. doi:10.1016/j.ultsonch.2004.01.038.

42. Salari D, Niaei A, Khataee A, Zarei M. Electrochemical treatment of dye solution containing C.I. Basic Yellow 2 by the peroxicoagulation method and modeling of experimental results by artificial neural networks. J Electroanal Chem. 2009;629(1-2):117125. doi:10.1016/j.jelechem.2009.02.002. 